\title{
Studi Evaluasi Analisa Perhitungan Kapasitas Daya Gardu Traksi Terhadap Kebutuhan KRL Jalur Depok-Manggarai
}

\author{
Awaluddin Saputra ${ }^{1}$ \\ ${ }^{1}$ Prodi Teknik Elektro UNPAM \\ Jln. Puspiptek Raya No 46 Buaran, Setu - Tangerang Selatan 15310 \\ awaluddin.saputra.1@gmail.com
}

\begin{abstract}
ABSTRAK
Dengan semakin meningkatnya jumlah penumpang, sehingga diperlukan penambahan armada KRL yang beroperasi. Hal ini harus diimbangi dengan kapasitas daya gardu traksi sebagai pensuplai daya KRL. Dapat disimak melalui Analisa dan pengukuran pada gardu traksi jalur Depok-Manggarai masih mencukupi untuk mensuplai kebutuhan daya KRL saat ini. Dimana pembebanan maksimal terjadi pada gardu traksi Pasar Minggu dengan persentase pembebanan 86,47 \% dari kapasitas daya gardu traksi eksisting. Sedangkan tegangan jatuh maksimal adalah 138,73 $\mathrm{V}$ atau 9,25\% dari tegangan nominal 1500 VDC diantara gardu traksi UI-Depok.
\end{abstract}

Kata kunci : Gardu traksi, KRL, kapasitas daya, tegangan jatuh

\begin{abstract}
With more increasing number of passengers, so that is required the addition fleet of electric train that operated. This should be offset by power capacity of traction substation as a supplier of electric train power. From the calculation and data analysis had been known that the Depok-Manggarai traction substation is still sufficient to supply the electric train power currently. Where the maximum loading occurs on Pasar Minggu traction substation with a percentage of $86.47 \%$ of the existing traction substations capacity. While the maximum drop voltage is $138.73 \mathrm{~V}$ or $9.25 \%$ of $1500 \mathrm{VDC}$ nominal voltage in between UI-Depok traction substation.
\end{abstract}

Keywords : Traction substation, electric train, power capacity, drop voltage

\section{PENDAHULUAN}

Diwilayah Jabodetabek, pergerakan penduduknya, dari satu kota ke kota yang lainnya sangatlah cepat. Terutama untuk para komuter, yaitu orang-orang yang biasanya bertempat tinggal di luar Jakarta, tetapi bekerja di Jakarta. Mereka melakukan perjalanan dari tempat tinggal mereka ke tempat bekerja hampir setiap hari pulang-pergi. Selain untuk bekerja, juga untuk aktifitas lainnya seperti kuliah dan bisnis. Oleh karena itu, diperlukan suatu moda transportasi yang efisien, yang dapat memudahkan aktifitas masyarakat setiap hari. Kereta rel listrik atau KRL merupakan salah satu moda transportasi favorit masyarakat. KRL memiliki beberapa kelebihan, diantaranya dapat mengangkut penumpang dalam jumlah besar, memiliki letak stasiun strategis yang berada di pusat kegiatan masyarakat Jabodetabek dan terhindar dari masalah kemacetan yang dapat terjadi apabila menggunakan moda transportasi lain seperti bis dan mobil.

Dengan beberapa kelebihannya ini serta pertumbuhan wilayah Jabodetabek yang sangat pesat, menyebabkan jumlah penumpang $\mathrm{KRL}$ mengalami peningkatan setiap tahunnya, sehingga jumlah armada $\mathrm{KRL}$ yang beroperasi juga harus ditambah. Penambahan jumlah KRL ini harus diimbangi dengan penambahan kapasitas daya gardu traksi yang berfungsi untuk mensuplai daya listrik ke $\mathrm{KRL}$. Karena $\mathrm{KRL}$ menggunakan motor listrik sebagai penggeraknya dengan memanfaatkan daya dari listrik aliran atas dengan gardu traksi sebagai salah satu komponen utamanya. Listrik aliran atas sendiri merupakan jaringan listrik 1500 VDC di wilayah KRL Jabodetabek. 
Dengan latar belakang tersebut, penulis akan melakukan studi evaluasi analisa perhitungan kapasitas gardu traksi terhadap kebutuhan KRL. Dari sini akan dilihat bagaimana kapasitas gardu traksi yang ada saat ini terhadap jumlah $\mathrm{KRL}$ yang beroperasi. Selain itu akan dilihat tegangan jatuh maksimal yang terjadi diantara gardu traksi yang beroperasi. Penelitian akan dilakukan pada beberapa gardu traksi KRL jalur Depok-Manggarai.

\section{TEORI}

\section{KRL}

$\mathrm{KRL}$ atau kereta rel listrik adalah kereta yang menggunakan tenaga listrik sebagai sumber daya penggeraknya. Dimana operasional KRL bersifat mandiri dan tidak memerlukan lokomotif penarik sebagai penggeraknya. Untuk sumber catu daya listriknya berasal dari jaringan katenari yang berada diatas $K R L$ yang disuplai melalui gardu-gardu traksi sepanjang lintasan KRL.

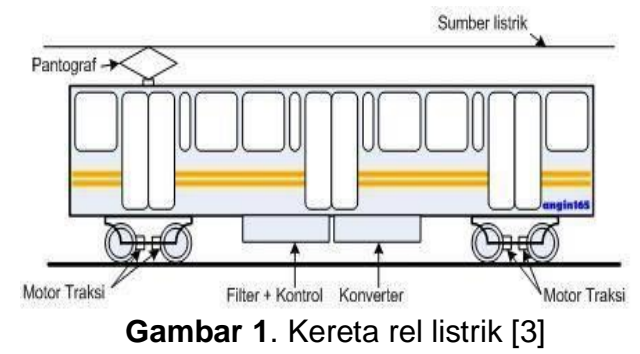

Untuk menyalurkan sumber listrik ke $\mathrm{KRL}$ digunakan piranti bernama pantograf seperti yang ditunjukkan pada gambar 1 . Pantograf digunakan sebagai aliran listrik $\mathrm{KRL}$ menuju konverter dihubungkan ke motor sehingga KRL dapat bergerak.

Pada jalur KRL Jabodetabek, terdapat beberapa jenis $K R L$ yang beroperasi dengan stamformasi berbeda. Stamformasi atau SF adalah banyaknya jumlah kereta yang tersambung dalam satu trainset atau keseluruhan rangkaian kereta. Beberapa jenis kereta yang ada dalam satu rangkaian $\mathrm{KRL}$ terdiri dari:

1. Trailer $(\mathrm{T})$ : Kereta gandengan (tanpa penggerak).

2. Trailer Cabin (TC): Kereta gandengan dengan kabin masinis.

3. $\operatorname{Motor}(\mathrm{M})$ : Kereta dengan penggerak motor traksi.
4. Motor Cabin (MC): Kereta dengan penggerak motor traksi dan kabin masinis.

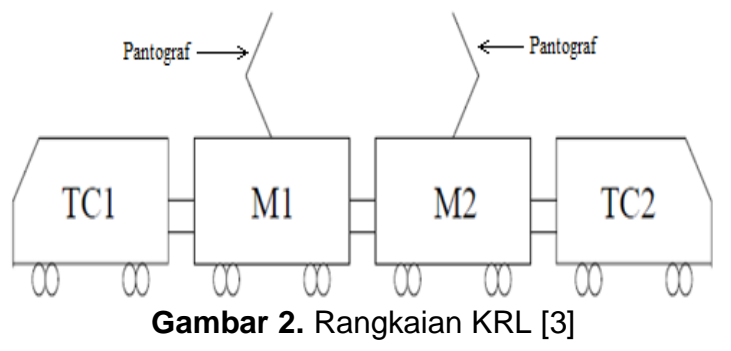

Pada gambar 2 merupakan rangkaian $\mathrm{KRL}$ yang terdiri dari dua kereta dengan penggerak motor traksi (M1 dan M2) dan dua kereta gandengan dengan kabin masinis (TC1 dan TC2). Kereta dengan penggerak motor traksi terdapat pantograf diatas kereta tersebut.

\section{Sistem Elektrifikasi}

Elektrifikasi adalah suatu proses pemberian tenaga listrik kepada mesinmesin listrik, salah satunya pada motor traksi penggerak KRL. Sistem elektrifikasi pada listrik aliran atas $\mathrm{KRL}$ terdapat dua jenis, yaitu:

1. Sistem elektrifikasi DC: 750 VDC, 1500 VDC dan 3000 VDC.

2. Sistem elektrifikasi AC: 15000 VAC dan Frekuensinya $16 \mathrm{~Hz}$.

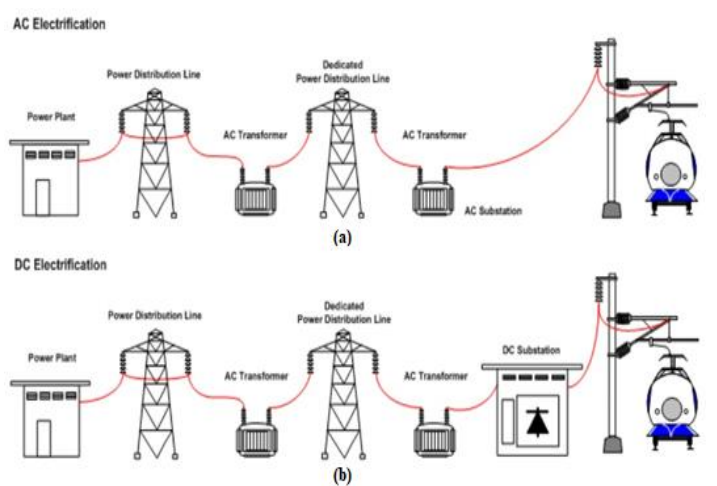

Gambar 3. (a) Sistem Elektrifikasi AC, (b) Sistem Elektrifikasi DC [5]

Pada gambar 3 (a) menunjukkan sistem elektrifikasi AC. Pada sistem ini listrik AC langsung disuplai dari trafo menuju jaringan katenari, tanpa melewati DC substation (gardu traksi DC). Sedangkan pada gambar 2.8 (b) menunjukkan sistem elektrifikasi DC. Pada sistem ini listrik DC disuplai menuju jaringan katenari, melalui DC substation (gardu traksi DC) untuk disearahkan terlebih dahulu dikarenakan 
sumber tegangan masih dalam bentuk AC.

\section{Listrik Aliran Atas}

Listrik Aliran Atas atau LAA adalah suatu sistem yang terdiri dari gardu traksi dan jaringan katenari yang berfungsi untuk menyalurkan daya dari sumber ke beban, yaitu kereta rel listrik (KRL) sehingga KRL dapat bergerak [6].

Gardu traksi merupakan salah satu bagian dari instalasi listrik aliran atas (LAA). Gardu traksi berfungsi mensuplai daya dengan tegangan 1500 VDC sebagai sumber tenaga KRL. Dimana sumber daya utama berasal dari suplai daya PLN dengan tegangan $20 \mathrm{KV}$ AC yang kemudian disearahkan dengan menggunakan silicon rectifier pada gardu traksi. Output dari gardu traksi berupa tegangan 1500 VDC kemudian disalurkan melalui jaringan katenari yang terhubung langsung dengan KRL. Pada gambar 4 menunjukkan diagram gardu traksi secara garis besar:

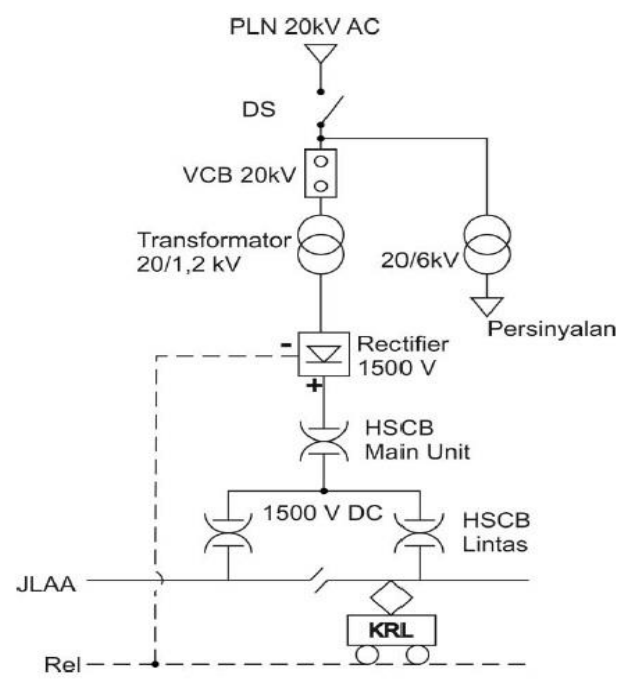

Gambar 4. Single Line Gardu Traksi KRL [6]

Sistem penyuplaian daya untuk listrik aliran atas menggunakan sistem penyuplaian dua sisi. Sistem ini menyuplai daya untuk $K R L$ dengan menggunakan 2 gardu traksi yang bersebelahan dalam satu petak jalan/petak jalan lain yang terhubung dengan interkoneksi secara paralel. Sehingga diperoleh total kapasitas daya yang sesuai dengan kebutuhan operasional KRL.

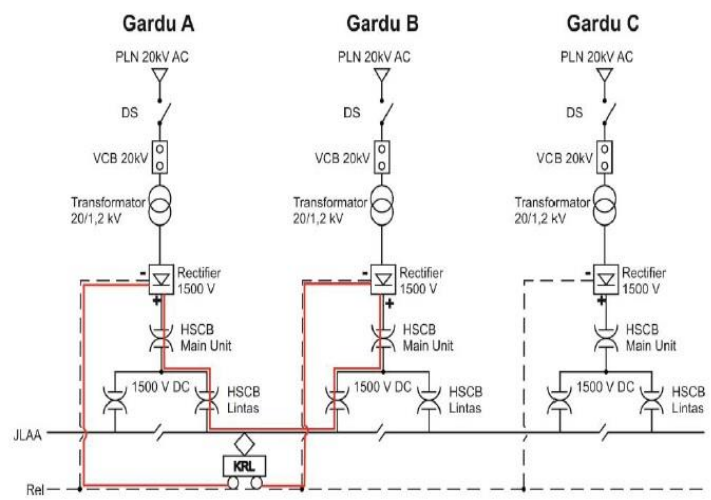

Gambar 5. Sistem Penyuplaian Dua Sisi Gardu Traksi [5]

Pada gambar 5 diperlihatkan sistem penyuplaian daya dengan menggunakan sistem penyuplaian 2 sisi, yaitu dari gardu traksi A dan B menyuplai daya untuk KRL secara paralel. Tegangan negatif dari rel dialirkan ke penyerah/rectifier gardu traksi A dan B. Pada saat terjadi gangguan yang menyebabkan gardu traksi tidak dapat beroperasi, maka gardu traksi lain (disebelahnya) bisa digunakan untuk mencatu daya $K R L$ pada petak jalan itu.

Sedangkan jaringan katenari disebut juga sistem saluran atas (overhead contact system) yaitu suatu saluran konduktor untuk mentransmisikan dan mensuplai daya dari gardu traksi ke kereta rel listrik (KRL) melalui pantograf [5]. Dimana saluran konduktor ini harus selalu berada didekat pantograf dan harus selalu menempel untuk mensuplai daya secara kontinyu, tidak terputus dan dengan kualitas yang baik.

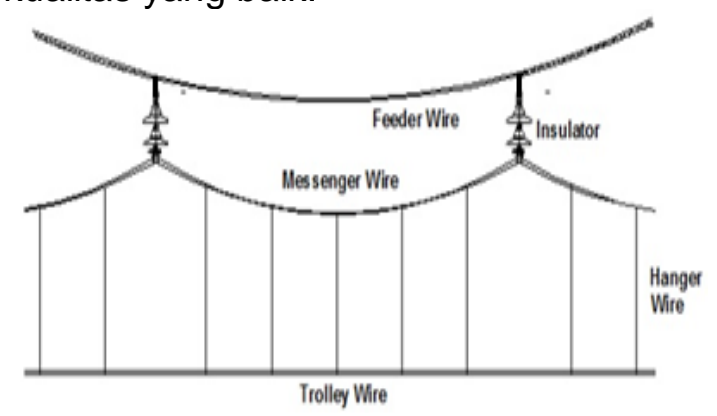

Gambar 6. Susunan Kawat pada Jaringan Katenari [6]

Pada gambar6 menunjukkan beberapa susunan kawan jaringan katenari yang terdiri dari:

1. Kawat Trolley, digunakan sebagai konduktor arus listrik dan sebagai saluran kontak dengan pantograf pada KRL. 
2. Kawat Messenger, digunakan untuk memikul beban kawa trolley atau disebut juga sebagai kawat pemikul.

3. Kawat Feeder, digunakan sebagai penyulang daya ke kawat trolley.

4. Kawat Hanger, digunakan untuk menggantung kawat trolley dan untuk mempertahankan kedudukan lurus kawat trolley.

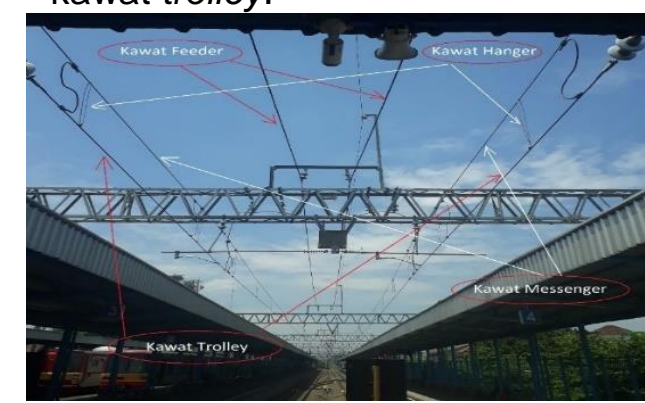

Gambar 7. Susunan Kawat pada Jaringan Katenari Listrik Aliran Atas

Pada gambar 7 menunjukkan susunan kawat pada jaringan katenari yang ada diatas rel di salah satu jaringan katenari di Jabodetabek.

\section{METODOLOGI}

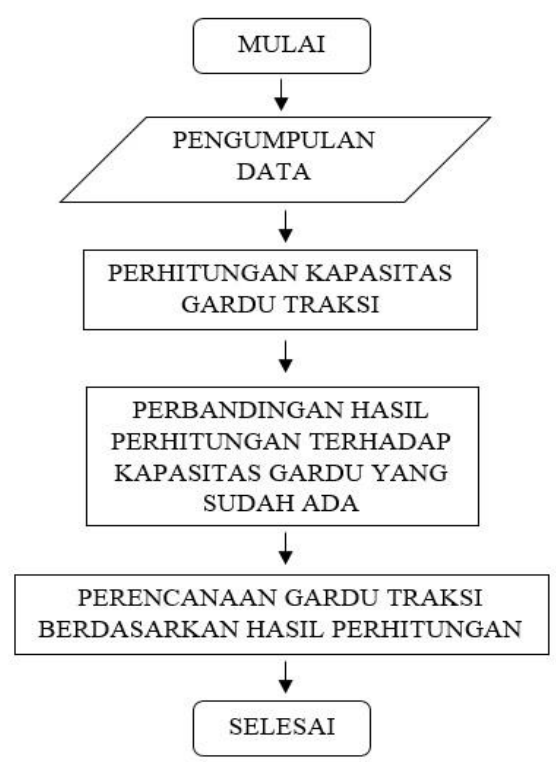

Gambar 8. Alur Proses Penelitian

Terdapat beberapa metode dalam penelitian $\mathrm{KRL}$, antara lain:

a. Penelusuran Literatur

Metode yang dilakukan pada tahap ini adalah pengumpulan data mengenai $\mathrm{KRL}$ dengan cara mencari referensi dari sumber yang akurat. b. Pengambilan Data

Pengambilan data dilakukan dengan melakukan kunjungan dan survey secara langsung ke PT. KAI DAOP I Unit Listrik Aliran untuk memperoleh data-data terkait gardu traksi yang diperlukan. Sedangkan untuk memperoleh data-data terkait $\mathrm{KRL}$ dilakukan dengan melakukan kunjungan dan survey secara langsung ke PT. KCJ DIPO KRL Depok. Data-data terkait gardu traksi yaitu lokasi gardu traksi, jarak antar gardu traksi, kapasitas daya gardu traksi eksisting dan spesifikasi gardu traksi. Sedangkan data-data terkait $K R L$ yaitu jenis $K R L$, berat $K R L$, kebutuhan daya motor traksi dan peralatan bantu $\mathrm{KRL}$ dan grafik perjalanan kereta (Gapeka).

c. Perhitungan Kapasitas Daya Gardu Traksi terhadap Kebutuhan KRL

Metode ini digunakan untuk melihat seberapa besar kondisi aktual pemakaian kapasitas daya gardu traksi. Jenis $K R L$ yang digunakan dalam perhitungan dengan menggunakan $K R L$ yang memiliki konsumsi daya dan berat $\mathrm{KRL}$ terbesar untuk melihat kondisi pembebanan maksimum gardu traksi. Kemudian diperoleh hasil kapasitas daya gardu traksi hasil perhitungan (daya terpakai). Dari sini dapat dibandingkan apakah kapasitas daya gardu traksi eksisiting (daya tersedia) masih mencukupi untuk mensuplai kebutuhan daya terpakai hasil perhitungan.

d. Perhitungan Tegangan Jatuh

Metode ini digunakan untuk melihat seberapa besar tegangan jatuh yang terjadi diantara dua buah gardu traksi dengan $\mathrm{KRL}$ sebagai beban yang berada diantara gardu traksi tersebut. Jumlah $K R L$ yang digunakan dalam perhitungan yaitu 2 buah $K R L$ di jalur hulu dan 2 buah $K R L$ di jalur hilir dengan jenis $K R L$ yang sama. Masingmasing $\mathrm{KRL}$ berada pada posisi $\mathrm{km}$ tertentu dan dapat dilihat tegangan jatuh yang terjadi di masing-masing posisi KRL tersebut.

e. Analisis 
Dalam analisis ini mengamati data hasil perhitungan kapasitas daya gardu traksi terhadap kebutuhan $\mathrm{KRL}$ dan hasil perhitungan tegangan jatuhnya. Sehingga dapat ditarik suatu kesimpulan apakah kapasitas daya gardu traksi eksisiting (daya tersedia) masih mencukupi untuk mensuplai kebutuhan daya terpakai hasil perhitungan dan apakah tegangan jatuh maksimal masih diperbolehkan dalam ketentuan tegangan jatuh.

\section{HASIL DAN PEMBAHASAN}

\section{Jarak Pengisian Gardu Traksi}

Jarak pengisian gardu traksi (L) merupakan jarak antara titik tengah interval antar gardu traksi satu dengan lainnya.

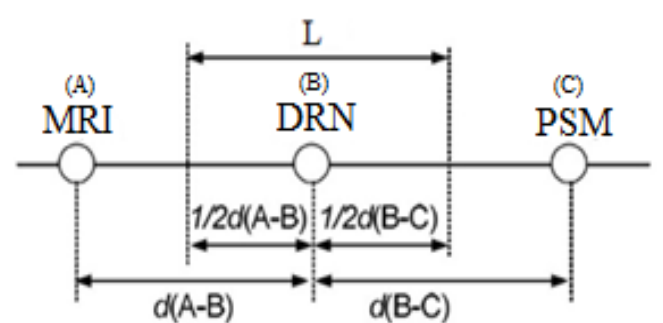

Gambar 9. Jarak Pengisian Gardu Traksi Duren Kalibata.

L Duren Kalibata (DRN)

$=1 / 2 \mathrm{~d}(\mathrm{~A}-\mathrm{B})+1 / 2 \mathrm{~d}(\mathrm{~B}-\mathrm{C})$

$=1 / 2($ Posisi DRN-MRI) $+1 / 2$ (Posisi

PSM-DRN)

$=1 / 2(14,890-9,890)+1 / 2(18,480-14,890)$

$=4,295 \mathrm{~km}$

Dengan menggunakan perhitungan yang sama untuk gardu traksi lainnya, maka diperoleh jarak pengisian pada tabel 1 dibawah ini:

Tabel 1. Jarak Pengisian Gardu Traksi

\begin{tabular}{|c|c|c|c|c|}
\hline No & Lokasi Gardu Traksi & $\begin{array}{c}\text { Jarak } \\
\text { Pengisian (L) } \\
(\mathrm{Km})\end{array}$ & $\begin{array}{c}\text { Ke Arah } \\
\text { Utara } \\
(\mathrm{Km})\end{array}$ & $\begin{array}{c}\text { Ke Arah } \\
\text { Selatan } \\
(\mathrm{Km})\end{array}$ \\
\hline 1 & Duren Kalibata (DRN) & 4,295 & 2,5 & 1,795 \\
\hline 2 & Pasar Minggu (PSM) & 3,332 & 1,795 & 1,537 \\
\hline 3 & Tanjung Barat (TNT) & 2,746 & 1,537 & 1,2085 \\
\hline 4 & Lenteng Agung (LNA) & 2,948 & 1,2085 & 1,7395 \\
\hline 5 & Universitas Indonesia & 4,44 & 1,7395 & 2,7 \\
\hline 6 & (UI) & 5,2 & 2,7 & 2,5 \\
\hline \multicolumn{5}{|c}{} \\
\hline
\end{tabular}

Pada tabel 1 dapat dilihat jika jarak antar gardu traksi mempengaruhi nilai jarak pengisian gardu traksi. Hal ini dapat berpengaruh terhadap pembebanan gardu traksi terkait.

\section{Perhitungan Daya Maksimum Per Jam (Y) Gardu Traksi}

Perhitungan daya maksimum per jam (Y) gardu traksi untuk mengetahui berapa pembebanan maksimum yang terjadi pada gardu traksi tiap jamnya. Berikut ini contoh perhitungan $Y$ pada gardu traksi Duren Kalibata (DRN):

$$
\begin{aligned}
\mathrm{Y}= & \mathrm{N} \times \mathrm{L} \times(\mathrm{w} \times \mathrm{W}+\mathrm{a} / \mathrm{V}) \\
= & 22 \times 4,295 \mathrm{Km} \times(529,6 \text { Ton } \times 53 \\
\mathrm{Wh} / \mathrm{ton} & \\
& \mathrm{km}+800 \mathrm{~kW} / 70 \mathrm{Km} / \mathrm{jam}) \\
= & 22 \times 4,295 \mathrm{Km} \times(28068,8+11428,57) \\
= & 3.732,11 \mathrm{~kW}
\end{aligned}
$$

Dengan menggunakan perhitungan yang sama tetapi dengan jumlah $K R L(N)$ yang berbeda-beda tiap jamnya, maka diperoleh perhitungan pada tabel 2:

Tabel 2. Daya Maksimum Per Jam Gardu Traksi Duren Kalibata.

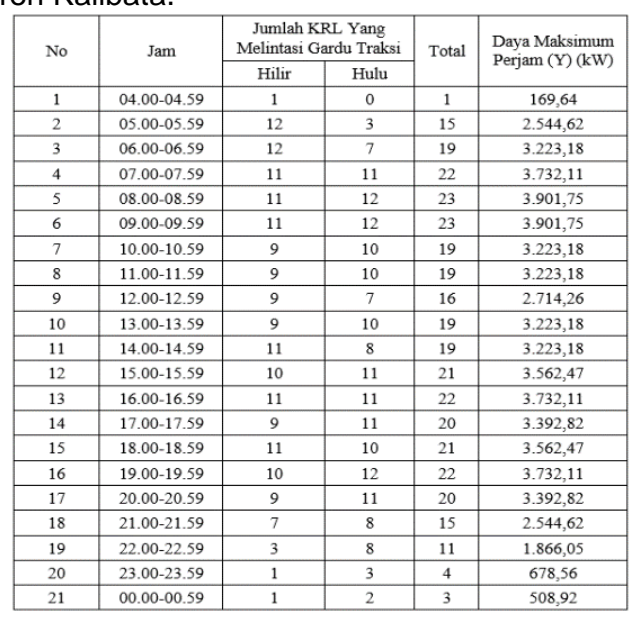

Berdasarkan tabel 2, jumlah $\mathrm{KRL}$ terbanyak tiap jamnya adalah $23 \mathrm{KRL}$. Pada kondisi ini daya maksimum per jam yang paling tinggi sebesar $3.901,75 \mathrm{~kW}$ pada jam 08.00-08.59 dan jam 09.0009.59. Daya maksimum per jam berbeda tiap jamnya tergantung jumlah $K R L$ yang melintas. 


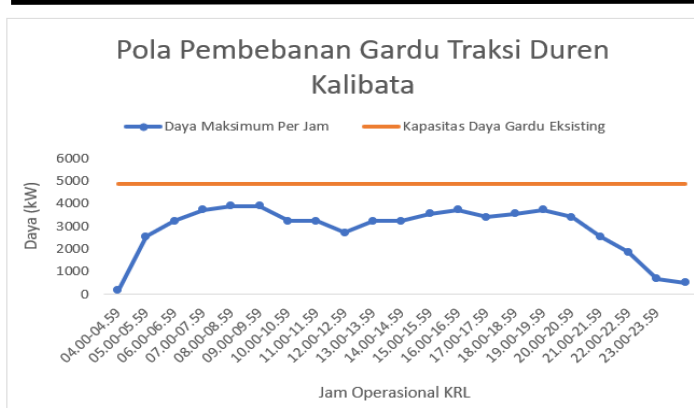

Gambar 10. Pola Pembebanan Gardu Traksi Duren Kalibata.

Gambar 10 merupakan grafik pola pembebanan gardu traksi Duren Kalibata yang dibuat berdasarkan data pada tabel 2 jika daya maksimum per jam gardu traksi Duren Kalibata setelah perhitungan masih mencukupi atau masih dibawah kapasitas daya gardu traksi eksisting. Perhitungan $Y$ berlaku untuk gardu traksi pada jalur Depok Manggarai lainnya, yaitu gardu traksi PSM, TNT, LNA, UI dan DP.

\section{Perhitungan Puncak Daya Maksimum (Z) dan Kapasitas Daya Gardu Traksi Yang Dibutuhkan.}

Untuk mengetahui kapasitas daya gardu traksi yang dibutuhkan, maka nilai puncak daya maksimum (Z) dapat diketahui, dimana:

$$
\mathrm{Z}=\mathrm{Y}+\mathrm{C} \sqrt{\mathrm{Y}} \text {, dengan } \mathrm{C}=1,7 \sqrt{\text { Imaks. }}
$$

Daya maksimum per jam (Y) digunakan nilai yang paling tinggi. Gardu Traksi Duren Kalibata (DRN).

Daya maksimum per jam $(\mathrm{Y})=3.901,75$ $\mathrm{kW}, \mathrm{C}=94,55$

$\mathrm{Z}=\mathrm{Y}+\mathrm{C} \sqrt{ } \mathrm{Y}$

$$
\begin{aligned}
Z & =3901,75+94,55 \sqrt{ } 3901,75 \\
& =9.807,69 \mathrm{~kW}
\end{aligned}
$$

Dengan menggunakan perhitungan yang sama tetapi dengan daya maksimum per jam (Y) yang berbeda untuk setiap gardu traksinya, diperoleh data tabel 3 sebagai berikut:

Tabel 3. Kebutuhan Kapasitas Daya Gardu Traksi Jalur Depok-Manggarai.

\begin{tabular}{|c|c|c|c|c|c|}
\hline No & Gardu Traksi & $\mathrm{Y}(\mathrm{kW})$ & $\mathrm{Z}(\mathrm{kW})$ & $\begin{array}{c}\mathrm{Z} / 2.5 \\
(\mathrm{~kW})\end{array}$ & $\begin{array}{c}\text { Kebutuhan } \\
\text { Kapasitas } \\
\text { Daya Gardu } \\
\text { Traksi }(\mathrm{kW})\end{array}$ \\
\hline 1 & Duren Kalibata & $3.901,75$ & $9.807,72$ & $3.923,09$ & $3.923,09$ \\
\hline 2 & Pasar Minggu & $3.158,53$ & $8.472,32$ & $3.388,93$ & $3.388,93$ \\
\hline 3 & Tanjung Barat & $2.603,03$ & $7.426,96$ & $2.970,78$ & $2.970,78$ \\
\hline 4 & Lenteng Agung & $2.794,52$ & $7.792,74$ & $3.117,09$ & $3.117,09$ \\
\hline 5 & Universitas Indonesia & $4.208,84$ & $10.342,83$ & $4.137,13$ & $4.208,84$ \\
\hline 6 & Depok & $4.929,27$ & $11.567,51$ & $4.627,00$ & $4.929,27$ \\
\hline
\end{tabular}

Untuk menentukan kebutuhan kapasitas daya gardu traksi dengan membandingkan hasil daya maksimum per jam (Y) dan puncak daya maksimum $(Z) / 2,5$. Nilai terbesar dari perbandingan $Y$ dan $Z / 2,5$ dipilih sebagai kapasitas gardu traksi.

\section{Perbandingan Kapasitas Gardu Traksi Eksisting dengan Hasil Perhitungan}

Berikut ini dapat dilihat bagaimana perbandingan kapasitas daya gardu traksi eksisting dengan kapasitas daya gardu traksi hasil perhitungan. Kapasitas daya gardu traksi hasil perhitungan diperoleh dari tabel 3 mengenai kebutuhan kapasitas daya gardu traksi.

Tabel 4. Kapasitas Daya Gardu Traksi Eksisting dan Hasil Perhitungan.

\begin{tabular}{|c|c|c|c|}
\hline Gardu Traksi & $\begin{array}{c}\text { Kapasitas Daya } \\
\text { Gardu Traksi } \\
\text { Eksisting }(\mathrm{kW}) \\
\text { (Daya Tersedia) }\end{array}$ & $\begin{array}{c}\text { Kapasitas Daya } \\
\text { Gardu Traksi Hasil } \\
\text { Perhitungan }(\mathrm{kW}) \\
\text { (Daya Terpakai) }\end{array}$ & $\Delta \%$ \\
\hline Duren Kalibata & 4.892 & $3.923,09$ & $80,19 \%$ \\
\hline Pasar Minggu & 3.919 & $3.388,93$ & $86,47 \%$ \\
\hline Tanjung Barat & 4.892 & $2.970,78$ & $60,73 \%$ \\
\hline Lenteng Agung & 3.919 & $3.117,09$ & $79,54 \%$ \\
\hline Universitas Indonesia & 6.623 & $4.208,84$ & $63,55 \%$ \\
\hline Depok & 7.482 & $4.929,27$ & $65,88 \%$ \\
\hline
\end{tabular}

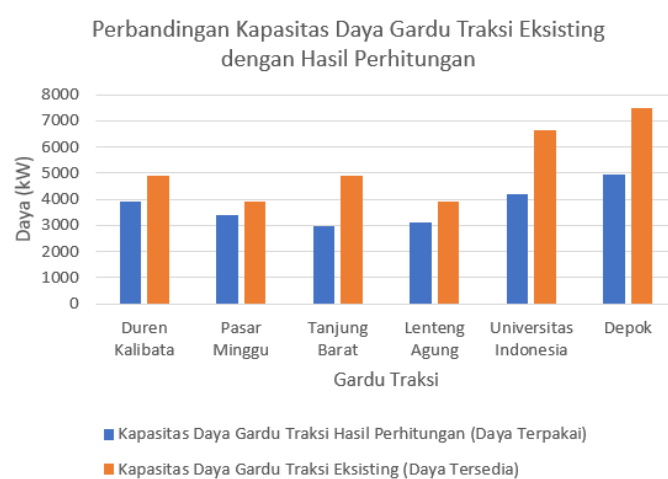

Gambar 11. Perbandingan Kapasitas Daya Gardu Traksi Eksisting dan Hasil Perhitungan.

Dari data pada tabel 4 dan gambar 11 dapat dilihat kapasitas daya gardu traksi eksisting dengan kapasitas daya gardu traksi hasil perhitungan. Dimana kapasitas daya gardu traksi eksisting merupakan daya tersedia yang dapat disuplai oleh gardu traksi. Sedangkan kapasitas daya gardu traksi hasil perhitungan merupakan 
daya terpakai oleh $\mathrm{KRL}$ berdasarkan perhitungan. Persentase daya terpakai tertinggi sebesar $86,47 \%$ atau $3.388,93$ kW dari $3.919 \mathrm{~kW}$ daya tersedia pada gardu traksi Pasar Minggu. Hal ini menunjukkan jika kapasitas daya gardu traksi eksisting pada jalur DepokManggarai masih cukup untuk mensuplai kebutuhan daya $\mathrm{KRL}$ yang beroperasi saat ini.

\section{Perhitungan Tegangan Jatuh}

Sesuai dengan Peraturan Menteri (PM) nomor 12 tahun 2011 tentang Persyaratan Teknis Peralatan Instalasi Listrik Perkeretaapian, maksimal tegangan jatuh yang diperbolehkan adalah $150 \mathrm{~V}$ atau $10 \%$ dari tegangan nominal 1500 V DC. Pada perhitungan tegangan jatuh ini terdapat $4 \mathrm{KRL}$ dengan masing-masing $2 \mathrm{KRL}$ pada jalur hulu (KRL dari Manggarai ke Depok) dan 2 $\mathrm{KRL}$ pada jalur hilir (KRL dari Depok ke Manggarai). Dimana masing-masing $K R L$ ini berada pada $\mathrm{km}$ tertentu $(d)$. Sehingga akan diperoleh nilai $V_{x}$ yaitu tegangan operasional (tegangan kerja) KRL yang merupakan nilai tegangan nominal jaringan katenari 1500 VDC $\left(V_{t h}\right)$ dikurangi dengan tegangan jatuh dimana posisi KRL berada $\left(R_{t h} I\right)$.

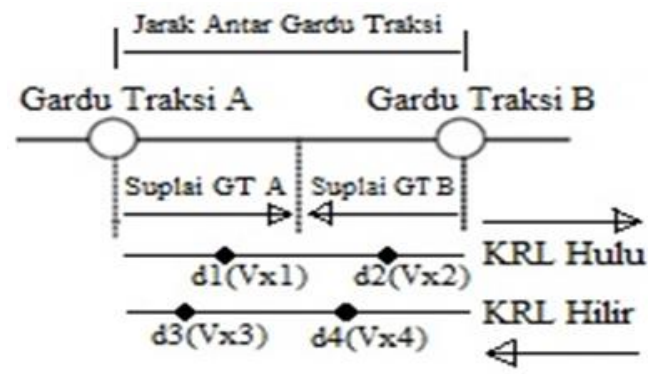

Gambar 12. Posisi KRL dan Tegangan Jatuh

Tegangan Jatuh Gardu traksi DRN-PSM

$V_{x}=V_{t h}-\frac{r_{o}\left(r_{o}+l r\right)+r^{2}\left(d l-d^{2}\right)}{2 r_{o}+l r} I$

$V_{x 1}=$

$1.500-$

$\frac{0,045(0,045+3,59 \times 0,0246)+0,0246^{2}\left(1,1 \times 3,59-1,1^{2}\right)}{2 \times 0,045+3,59 \times 0,0246} \times 3.093,3$

$$
=1.500-132,82
$$$$
=1.367,18 \mathrm{~V}
$$

$V_{x 2}=1.500-125,08=1.374,92 \mathrm{~V}$

$V_{x 3}=1.500-129,49=1.370,51 \mathrm{~V}$

$V_{x 4}=1.500-129,30=1.370,70 \mathrm{~V}$

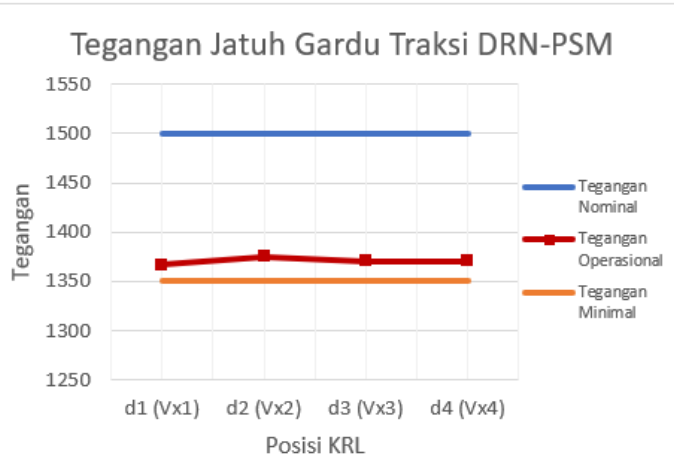

Gambar 12 Tegangan Jatuh Gardu Traksi DRNPSM

Terjadi tegangan jatuh tertinggi $132,82 \mathrm{~V}$ dari tegangan nominal $1500 \mathrm{~V}$ diantara gardu traksi DRN-PSM. Nilai ini masih dalam batas maksimal tegangan jatuh yang diperbolehkan, yaitu $150 \mathrm{~V}$ dan nilai tegangan operasional masih diatas tegangan minimal seperti yang ditunjukkan pada gambar 4.5.

Dengan menggunakan perhitungan yang sama untuk tegangan jatuh diantara gardu traksi lainnya pada jalur DepokManggarai, maka diperoleh data pada tabel:

Tabel 5 Tegangan Jatuh Maksimal Gardu Traksi Jalur Depok-Manggarai

\begin{tabular}{|c|c|c|}
\hline Gardu Traksi & $\begin{array}{c}\text { Tegangan } \\
\text { Nominal }\end{array}$ & $\begin{array}{c}\text { Tegangan Jatuh } \\
\text { Maksimal }\end{array}$ \\
\hline DRN-PSM & 1500 VDC & 132,82 VDC \\
\hline PSM-TNT & 1500 VDC & 124,82 VDC \\
\hline TNT-LNA & 1500 VDC & 114,39 VDC \\
\hline LNA-UI & 1500 VDC & 131,42 VDC \\
\hline UI-DP & 1500 VDC & 138,73 VDC \\
\hline
\end{tabular}

Tegangan jatuh maksimal pada jalur Depok-Manggarai terjadi diantara gardu traksi UI-DP, yaitu sebesar 1361,27 V dari tegangan nominal $1500 \mathrm{~V}$ atau terjadi tegangan jatuh $138,73 \mathrm{~V}$. Hal ini terjadi karena gardu traksi UI-DP memiliki jarak antar gardu traksi yang paling besar, yaitu $5,4 \mathrm{~km}$.

\section{KESIMPULAN}

Dalam penelitian ada beberapa kesimpulan, yaitu:

1. Hasil perbandingan kapasitas daya gardu traksi hasil perhitungan dan kapasitas daya gardu traksi eksisting jalur Depok-Manggarai menunjukkan jika kapasitas daya gardu traksi eksisting masih mencukupi untuk 
kebutuhan operasional KRL saat ini. Dimana pembebanan paling maksimal terjadi pada gardu traksi Pasar Minggu yang memiliki persentasi pembebanan $86.47 \%$ dari kapasitas daya gardu eksisting.

2. Tegangan jatuh maksimal pada jalur Depok-Manggarai terjadi diantara gardu traksi UI-DP, yaitu sebesar $1361,27 \mathrm{~V}$ dari tegangan nominal $1500 \mathrm{~V}$ atau terjadi tegangan jatuh $138,73 \mathrm{~V}$. Hal ini terjadi karena gardu traksi UI-DP memiliki jarak antar gardu traksi yang paling besar, yaitu $5,4 \mathrm{~km}$. Nilai tegangan jatuh maksimal yang terjadi pada jalur DepokManggarai tetap dengan maksimal tegangan jatuh yang diperbolehkan $10 \%$ dari tegangan nominal $1500 \mathrm{~V}$ (Maksimal tegangan jatuh $150 \mathrm{~V}$ ).

\section{UCAPAN TERIMAKASIH}

Dalam penyusunan penelitian dialkukan melalui tahapan-tahapan, dan tidak lupa saya ucapkan terima kasih kepada:

1. Bapak Dr. Ing. Agus Sofwan.

2. Bapak Syaiful B., S.T., M.Eng.Sc., Ph.D.

3. Bapak Seflahir D., S.T., M.Pd.T.

4. Teman seperjuangan.

\section{DAFTAR PUSTAKA}

[1] Istanto W, Djatmiko. 2010. Elektronika Daya. Bahan Ajar. Yogyakarta: Program Studi Pendidikan Teknik Elektro UNY.

[2] Bien, Liem Ek; Kasim, Ishak; dan Hartanto, Hendry. 2006. Sistem Kendali Kereta Otomatis Pada Kereta
Rel Listrik VVVF. Jurnal IImiah Teknik Elektro, Vol. 5, No. 2, 41-60.

[3] AS, Hartono. 2012. Lokomotif dan Kereta Diesel di Indonesia. Jakarta: Ilalang Sakti Komunikasi.

[4] Trijaya, Tomy. 2010. Diklat Fungsional - Pengetahuan Jaringan Katenari Listrik Aliran Atas. Bandung: BPL-ST

[5] Graha, Aria. 2005. Buku Pedoman Perencanaan Listrik Aliran (LAA). Bandung: PT. Kereta Api (Persero)

[6] PT KAI. 2016. Ketentuan Umum Instalasi Listrik Aliran Atas Arus Searah dengan Tegangan $1500 \mathrm{~V}$. Bandung: PT. KAI

[7] PT KAI. 2016. Kapasitas Daya Listrik Aliran Atas. Jakarta: PT. KAI

[8] Ichtiarso, Cesar. 2015. "Evaluasi Peningkatan Kapasitas Daya Gardu Listrik Aliran Atas Jalur Lintas Tengah Sebagai Suplai Kereta Rel Listrik di Wilayah PT KAI DAOP I Jakarta".

[9] Haroen, Yanuarsyah. 2013. "Power Evaluation of Jakarta DC Railway Substation to Meet 1.2 Million Passengers per Day". The 4th International Conference on Electrical Engineering and Informatics ICEEI.

[10] González, D. dan Manzanedo, F. 2008. Optimal Design of a D.C. Railway Power Supply System. IEEE Electrical Power and Energy Conference-Energy Innovation

[11] PT KAI. 2016. Peta Elektrifikasi Listrik Aliran Atas DAOP I Jakarta 2016. Jakarta: PT. KAI

[12] Rizal, Chairul. 2017. Spesifikasi Kereta Rel Listrik (KRL) Jabodetabek. Depok: Dipo KRL Depok

[13] PT. KAI. 2017. Grafik Perjalanan Kereta Api (GAPEKA) 2017. Jakarta: PT.

$\mathrm{KAI}$ 